\title{
Functional disruption of macrophage migration inhibitory factor (MIF) suppresses proliferation of human H460 lung cancer cells by caspase-dependent apoptosis
}

\author{
Yubiao Guo ${ }^{1 *}$, Junna Hou', Yifeng Luo ${ }^{1}$ and Dujuan Wang ${ }^{2}$
}

\begin{abstract}
Background: Macrophage migration inhibitory factor (MIF) is important in regulating cell proliferation and apoptosis in both normal and cancerous cells, and may be important in cancer progression and metastasis. In human non-small cell lung cancer (NSCLC), the underlying mechanisms responsible for MIF-dependent regulation of cellular proliferation, and cell death remain poorly appreciated.

Methods: The human $\mathrm{H} 460$ lung cancer cell-line was treated with an optimally determined dose of $50 \mathrm{pmol} / \mathrm{ml}$ MIF siRNA, following which cell proliferation, cell cycle and apoptosis were analyzed. Additionally, known pathways of apoptosis including expression of Annexin- $V$, enhanced production of caspases- 3 and -4 and expression of the Akt signaling protein were assessed in an attempt to provide insights into the signaling pathways involved in apoptosis following disruption of MIF expression.

Results: Specific siRNA sequences markedly decreased MIF expression in H460 cells by 2 to 5 -fold as compared with the negative control. Moreover, MIF miRNA dampened not only cellular proliferation, but increased the frequency of apoptotic cells as assessed by cell-surface Annexin-V expression. Entry of cells into apoptosis was partly dependent on enhanced production of caspases -3 and -4 while not affecting the expression of either caspase-8 or the Akt signaling pathway.

Conclusions: In a model of NSCLC, knockdown of MIF mRNA expression dampened H460 proliferation by mechanisms partly dependent on entry of cells into apoptosis and enhanced production of caspase- 3 and -4 . MIF expression may thus be important in NSCLC progression. Targeting MIF may have clinical utility in the management of human lung cancer.
\end{abstract}

Keywords: Macrophage migration inhibitory factor (MIF), Non-small cell lung cancer, Proliferation, Apoptosis, Caspase-3, Caspase-4

\section{Introduction}

Lung cancer is the leading cause of cancer-related death in the world, and accounted for approximately 157,300 deaths in the United States in 2010 [1]. It is estimated that $85-90 \%$ of lung cancers are of the non-small-cell lung cancer type (NSCLC). With current therapies lacking adequate specificity and efficacy, the median overall survival rate of patients with metastatic NSCLC remains at

\footnotetext{
* Correspondence: guoyubiao@hotmail.com

${ }^{1}$ Department of Pulmonary Medicine, the First Affiliated Hospital of Sun Yat-Sen University, Guangzhou 510080, China

Full list of author information is available at the end of the article
}

approximately 1 year [2,3]. Moreover, It is clear that chemo-therapy has reached a plateau of activity in the treatment of NSCLC [4]. Thus, novel treatment strategies for targeting human lung cancer are urgently warranted.

Macrophage migration inhibitory factor (MIF) is considered a multifunctional cytokine secreted by a variety of cells such as macrophages [5], lymphocytes [6], eosinophils [7], epithelial cells [8], and endothelial cells [9], which importantly, is over-expressed in many different lung cancers [10-12]. In human lung adenocarcinoma, MIF modulates tumor cell migration and invasion, in 
part by inducing the activation of the Rho GTPase Rac, and membrane lipid raft stabilization; features that are important in both driving and sustaining tumor cell invasion [13-15].

The functions of MIF are predominantly immunoregulatory, serving important roles in inflammation, cellmediated and innate immunity [16-19]. In addition, MIF displays a dominant role in diseases that are characterized by pro-inflammatory pathways, such as the severity of rheumatoid arthritis [20], cardiac dysfunction that is seen in sepsis [21], Crohn's disease [22], and many different cancers [23-25].

Since the discovery of MIF almost 50 years ago, more recent work has identified MIF as a key factor in the development and progression of human cancers, and particularly in the metastatic potential of colorectal and lung tumors [13,23-29]. Given the known functions of MIF in pro-inflammatory pathways, and the weight of evidence associating inflammatory pathways and the development of cancer, it comes as no surprise that MIF is emerging as a key player in the progression and growth of many tumors [23-29]. It is thought that the ability of MIF to suppress the anti-inflammatory effects of glucocorticoids is central to the inflammatory promoting functions of MIF, for example in diseases such as acute respiratory distress syndrome [30,31].

The ability of MIF to suppress anti-inflammatory pathways is highly relevant to the growing appreciation of chronic inflammatory pathways promoting tumor growth and metastatic development. In host immune defense, inflammatory cytokines and other inflammatory mediators assist in the clearance of infection, eradication of tumors and in the repair or maintenance of intact tissues and organs. However, the inflammatory milieu, and particularly in chronic inflammation, provides an environment that assists tumor development and metastasis. The biological activities of MIF are thought to contribute to these processes by inhibiting the regulatory functions of p53 and thus blocking apoptosis (programmed cell death). It is thought that this is achieved by certain tumors sustaining the activation of the ERK signaling pathway via the functional activation of MIF. Such conditions not only attenuate cell death, they also promote tumor cell invasion and induce the expression of COX-2 and PGE-2 which collectively induce tumor cell growth, tumor cell survival and metastasis. These are conditions that favor de novo angiogenesis, thus providing a blood supply to metastatic tumors [16,32-34].

In the specific setting of non-small cell lung cancer (NSCLC), monocyte-derived macrophage secretion of MIF is augmented by NSCLC cells, and secretion of MIF may contribute to local angiogenic activity and tumor metastasis in cell culture models and mouse models of tumor development [11,35-37]. A major breakthrough in our understanding of the role of MIF in tumor metastasis in NSCLC was the identification of CD74 (the invariant chain of the HLA class II peptide) as the cell surface receptor for binding MIF [10,38]. Although very little is known of the relevance of CD74 in many lung cancers, the expression of CD74 in gastric carcinoma has been associated with a poor prognosis $[39,40]$. More recently, association of CD74 and MIF co-expression in lung cancers [10], and the identification of MIF by label-free proteomic approaches as one of many promising biomarkers in NSCLC [41], provides additional evidence of the importance of MIF in lung cancer development and progression.

Thus, in the current study, we set out to employ H460 cells as a relevant model system to explore the functional role of MIF in NSCLC. Further, we wished to assess the molecular mechanisms responsible for the anti-tumor effects of functionally dampening MIF expression using specific siRNA sequences. We found that MIF siRNA transfection inhibited both the proliferation and induced the apoptosis of $\mathrm{H} 460$ cells through mechanisms that were dependent on enhanced production of caspase-3 and caspase-4, sustained expression of the Akt/protein kinase B (phosphoinositide 3-kinase, PI3K) signaling pathway, proliferation arrest and promotion of an apoptotic mode of programmed cell death.

\section{Materials and methods}

\section{Cell culture maintenance and transfection}

The human non-small cell lung cancer cell-lines H460 and A549, were both obtained from the Cell Bank of the Animal Experiment Center, North School Region, Sun Yat Sen University, Peoples Republic of China. H460 cells were cultured in RPMI-1640 medium (GIBCO, USA) and A549 cells were cultured in DMEM medium (GIBCO, USA) where both cultures were supplemented with $10 \%$ newborn calf serum. Both cell-lines were maintained in a fully humidified incubator at $37^{\circ} \mathrm{C}$ and an atmosphere of $5 \% \mathrm{CO}_{2}$ in air.

For transfection experiments, two independent siRNA species were designed to target knockdown of functional MIF expression and were obtained from Invitrogen (San Diego, CA, USA). The sequences of each miRNA species were:

1) Sense 5 -AUAgUUGauguagaCCCUGUCCGGG-3' Antisense $5^{\prime}$-CCCGGACAGGGUCUACAUCAACUAU-3

2) Sense $5^{\prime}$-UUGgugUUUACGAUGAACAUCGGCA- ${ }^{\prime}$ Antisense $5^{\prime}$-UGCCGAUGUUCAUCGUAAACACCAA-3

The negative control siRNA was also obtained from Invitrogen, and had the following sequence:

Sense 5'-GCGCGCUUUGUAGGAUUCGdTdT -3', Antisense $5^{\prime}$-CGAAUCCUACAAAGCGCGCdTdT -3. 
Cell-lines at an exponential phase of proliferation were seeded into 6-well culture plates, $1.5 \times 10^{5}$ cells per well. When the confluence of the cells approximated $30-40 \%$ of the available surface area of the culture wells, the cells were transfected with $50 \mathrm{pmol} / \mathrm{ml}$ siRNA (a dose that was found to be optimal in dose-dependent experiments), using lipofectamine 2000 reagent (Invitrogen, USA) following the manufacture's protocol. Cells transfected with the negative control siRNA were used to control for the specificity of the miRNA MIF knockdown studies. The transfection efficiency was monitored by observation of the frequency of immunofluorescent positive cells by microscopic examination.

\section{Determination of cell proliferation by MTT assay}

Approximately $5 \times 10^{3}$ cells per well were seeded into 96well plates and transfected with MIF siRNA or negative control siRNA, both at a dose of $50 \mathrm{pmol} / \mathrm{ml}$ using lipofectamine 2000 reagent (Invitrogen, USA) following the manufacture's protocol. At the indicated time points of $24 \mathrm{~h}, 48 \mathrm{~h}$ and $72 \mathrm{~h}$ post-transfection, the extent of cellular proliferation was measured by MTT assay. This was done by adding MTT reagent $(20 \mu \mathrm{l})$ to each well and incubating the plates for an additional $4 \mathrm{~h}$ at $37^{\circ} \mathrm{C}$. At the conclusion of the assay, the medium was aspirated, and dimethyl sulfoxide $(150 \mu \mathrm{l})$ was added to each well to dissolve the formazan product following metabolism of the MTT reagent. Absorbance values of the formazan product were measured at a wavelength of $490 \mathrm{~nm}\left(\mathrm{~A}_{490}\right)$. Each experiment was repeated at least three times.

\section{Plate cloning assay}

A plate-cloning assay was also carried out $24 \mathrm{~h}$ after the transfection of MIF siRNA, In this assay, H460 cells were collected, trypsinized, and plated into 6-well plates of 200 cells per well. Cells were cultured in complete medium ( $2 \mathrm{ml} /$ well) continuously for 10 days, following which they were fixed, stained, and observed for the formation of visible cultured cell clones by light microscopy. Aggregation of $\geq 50$ cells was considered as a clone. The percentage of clone formation was calculated according to the following equation:

Percentage of clone formation

$=($ clone number $/$ plated cell number $) \times 100 \%$

\section{Flow cytometric determination of $\mathrm{H} 460$ Apoptosis}

The H460 cell-line was seeded at a density of $1.5 \times 10^{5}$ cells/well into 6-well culture plates under conditions described above. Cells were treated with either MIF siRNA or NC siRNA (for the control group) for a period of $48 \mathrm{~h}$ of continuous culture in the presence of these siRNA species. At the conclusion of the assay, cells were harvested by trypsinization, washed three times in PBS and resuspended in $0.5 \mathrm{ml}$ PBS. Immediately after resuspension of the cells, propidium iodide (PI) and a FITCconjugated monoclonal antibody specific for Annexin $\mathrm{V}$ (KaiGi Technology, Guangzhou, China) were incubated with the cells at $4^{\circ} \mathrm{C}$ for a period of 30 minutes. Cell apoptosis was measured using Flow cytometry (Becton Dickinson Biosciences, Inc., NJ, USA).

\section{Western immunoblotting}

Treated H460 cells were lysed in a lysis buffer supplemented with a protease inhibitor cocktail (Tissue or Cell Total Protein Extraction Kit, Shanghai, China). After 10 min incubation on ice, the cell suspension was centrifuged at $12000 \mathrm{~g}$ for $20 \mathrm{~min}$ at $4^{\circ} \mathrm{C}$. Soluble protein fractions were then analyzed by Western immunoblotting performed as follows: First, protein samples were resolved on 12-15\% SDS-PAGE gels. The protein bands were transferred onto PVDF membranes (Millipore, USA) which were then blocked overnight in TBS-Tween 20 (TBST) buffer containing $5 \% \mathrm{w} / \mathrm{v}$ skimmed milk proteins. The membranes were washed three times with TBST for 10 min each. Second, the membranes were incubated with an appropriate dilution of a specific primary antibody targeted against MIF (Abcam, USA), caspases- $3,-4$ and -8 and AKT (all obtained from Cell Signaling Technology, USA) with gentle shaking overnight at $4^{\circ} \mathrm{C}$. Thirdly, the membranes were washed thoroughly with TBST and incubated with a HRP-conjugated secondary antibody (Cell Signaling Technology, USA) for $1 \mathrm{~h}$ at room temperature. Finally, after the membranes were washed with TBST, the resolved and transferred protein signals were detected by enhanced chemiluminescence (ECL). The stained bands were scanned and the relative optical densities measured for semi-quantitation of the relative expression levels of each ECL detected protein band.

\section{Statistical analysis}

The results were expressed as the arithmetic mean \pm one standard deviation (SD) about the mean. All data were the product of at least three independent experiments. The data were analyzed by one-way analysis of variance (ANOVA) using SPSS 16.0 statistical analysis software (SPSS Inc, Chicago, IL). An alpha value of $P<0.05$ was considered statistically significant.

\section{Results}

MIF is expressed in $\mathrm{H} 460$ and A549 cells and siRNA-mediated MIF knockdown in $\mathrm{H} 460$ cells

Prior studies have reported that MIF is over-expressed in human lung adenocarcinomas [12,13,29]. We evaluated the expression of MIF in H460 and A549 cells, and found that the expression of MIF was highest in $\mathrm{H} 460$ cells (Figure 1). In pilot experiments, we found that a 


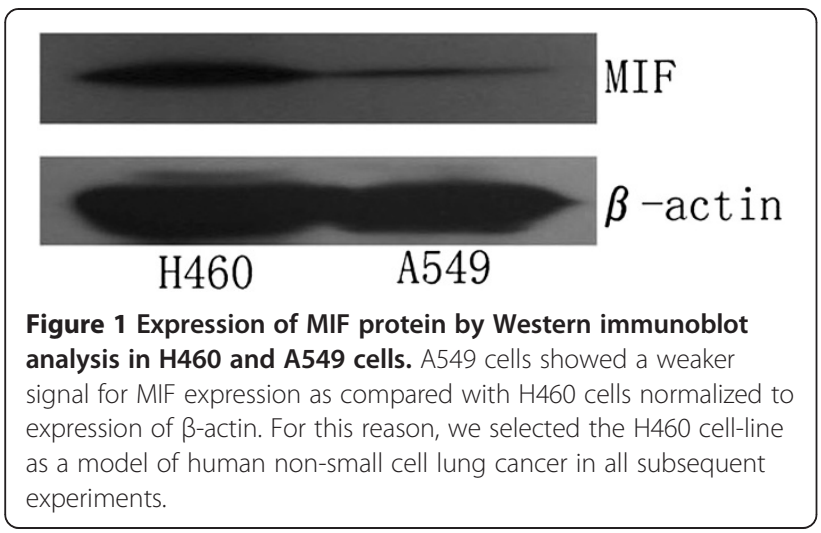

concentration of $50 \mathrm{pmol} / \mathrm{ml}$ of specific MIF siRNA was optimal for disrupted expression of MIF (see below). The transfection efficiency was monitored by immunofluorescence observation and we found that the transfection efficiency was more than 70\% (Figure 2).

In addition, we found that at siRNA concentrations greater than $50 \mathrm{pmol} / \mathrm{ml}$, the extent of cell death increased dose-dependently with increasing siRNA concentrations. Therefore, we selected a dose of $50 \mathrm{pmol} / \mathrm{ml}$ for optimal transfection of $\mathrm{H} 460$ cells with siRNA for all the following experiments.
After incubating the cells for $48 \mathrm{~h}$ with the MIF siRNA species, we determined the relative expression of MIF knockdown by Western immunoblotting (Figure 3). We found that the expression of MIF protein was significantly reduced in the cells transfected with MIF siRNAs as compared those cells treated with the NC siRNA. These observations suggested that MIF siRNAs could dampen the functional expression of MIF in H460 cells very efficiently (Figure 3 ).

\section{Determination of the effects of MIF siRNA on H460 cellular proliferation}

Using the MTT metabolic and viability assay, the cellular proliferation and viability of treated $\mathrm{H} 460$ was determined (Figure 4A). We found that in $\mathrm{H} 460$ cells treated with MIF siRNA displayed significantly reduced proliferation as compared with cells treated with the NC siRNA control sequence $(\mathrm{p}<0.05)$. In addition, the plate cloning assay indicated that MIF siRNA inhibited the proliferation of $\mathrm{H} 460$ cells (Figure 4B) which was concordant with the data obtained by MTT assay.

We also assessed the cell cycle dynamics (Figure 5) of H460 cells treated with the NC siRNA control (A), and following treatment with either MIF siRNA1 (B), or MIF siRNA2 (C). In these cell cycle analyses, we could not
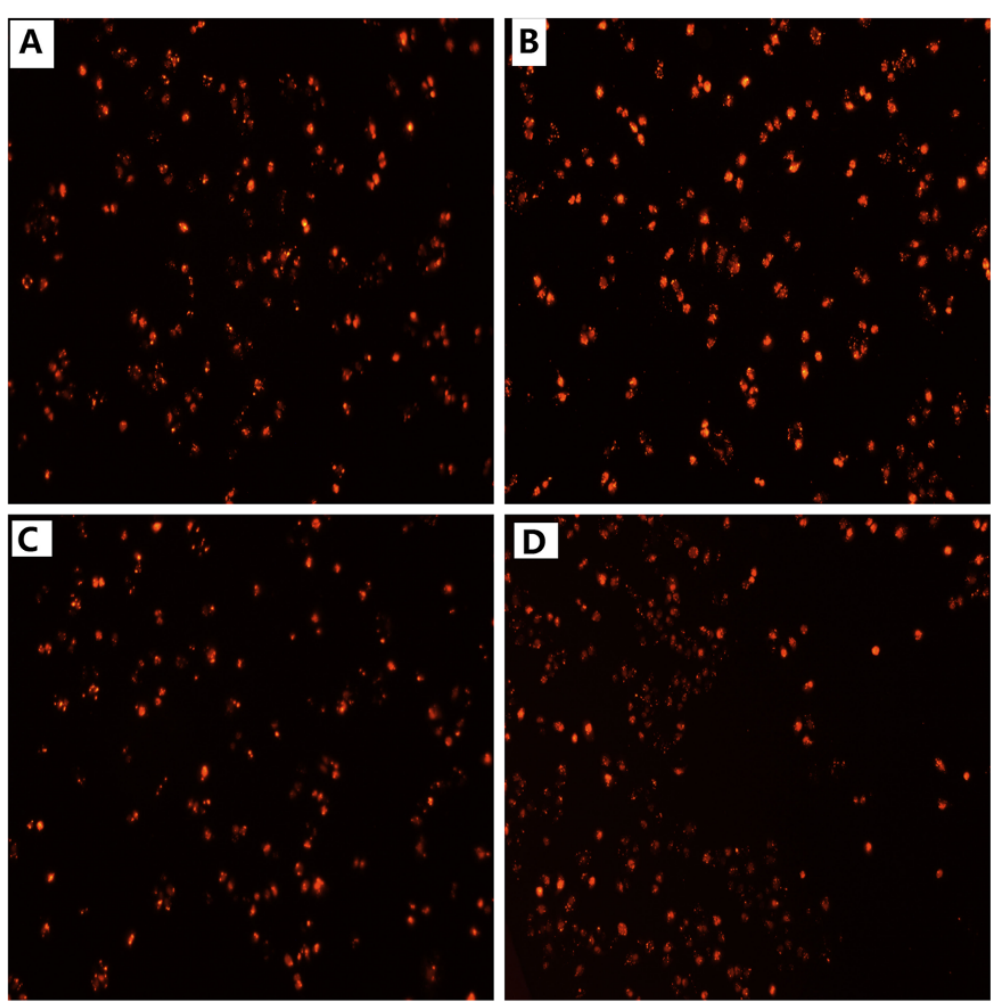

Figure 2 Dose-dependent detection of siRNA transfection efficacy by immunofluorescence observation. The following doses of siRNA were assessed: A: $30 \mathrm{pmol} / \mathrm{ml}$. B: $50 \mathrm{pmol} / \mathrm{ml}$. C: $70 \mathrm{pmol} / \mathrm{ml}$. D: $100 \mathrm{pmol} / \mathrm{ml}$. By visual inspection of the fluorescence intensity and frequency of cells transfected, we selected a dose of $50 \mathrm{pmol} / \mathrm{ml}$ in subsequent experiments. 


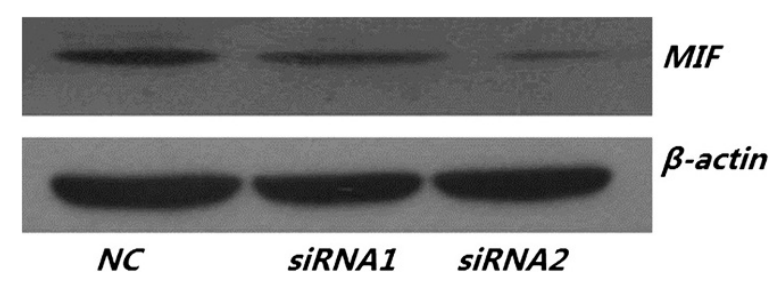

Figure 3 siRNA-mediated knockdown of MIF expression in H460 cells detected by Western blot. In MIF siRNA-transfected H460 cells (A), we observed a an approximately two (siRNA 1) to five (siRNA2) fold weaker signal of MIF protein expression as compared with the negative control (NC) group normalized to the expression of $\beta$-actin (B).

determine any significant effect on the major cell cycle compartments wherein the G0/G1 peaks, S-phase and G2/M phases of the cell cycle appeared quite similar (Figure 5). Nonetheless, collectively, these data suggest an important functional role for MIF in lung tumor cell proliferation.

\section{Knockdown of functional MIF expression promotes apoptosis}

Consistent with the observations indicating apoptotic modes of cell death in $\mathrm{H} 460$ cells treated with MIF
siRNA (Figure 5), we next pursued multi-parameter flow cytometric analysis of siRNA transfected H460 cells to obtain more sensitive and quantitative details of a possible apoptotic mode of cell death (Figure 6A and B). Following $48 \mathrm{~h}$ of culture of MIF siRNA transfected H460 cells, flow cytometry was used to quantify the expression of Annexin- $\mathrm{V}$ in the absence of PI staining following MIF siRNA treatment (Figure 6A), a condition which indicated apoptosis. We found that in cells treated with both MIF siRNA1 and MIF siRNA2, displayed significantly higher levels of Annexin- $V$ staining (18.09 \pm $0.41 \%$ and $23.38 \pm 2.67 \%$ respectively) as compared their negative control siRNA treated counterparts $(5.87 \pm$ $1.05 \%, \mathrm{p}<0.05$, Figure $6 \mathrm{~A}$ and $6 \mathrm{~B})$. These observations collectively suggested that MIF may serve important regulatory roles in apoptosis.

\section{Pathway analysis by western immunoblotting}

In an attempt to elucidate the putative mechanisms responsible for the possible anti-tumor effect of MIF siRNA, we assessed the relative expression levels of proteins thought to be associated with apoptosis and cellular proliferation. We found that the expression of the cleaved band (i.e. caspase-3 and -4) of pro-caspase-3 and -4 were significantly higher in the MIF siRNA

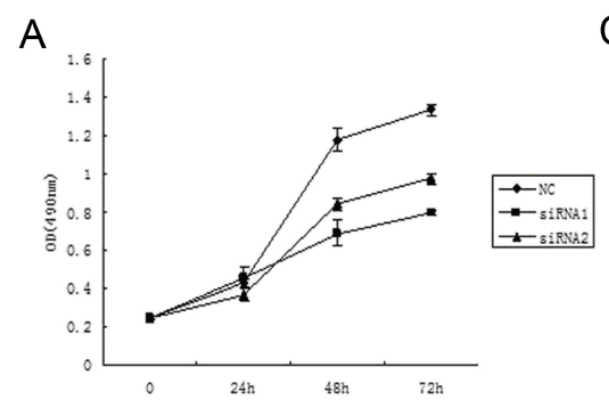

B

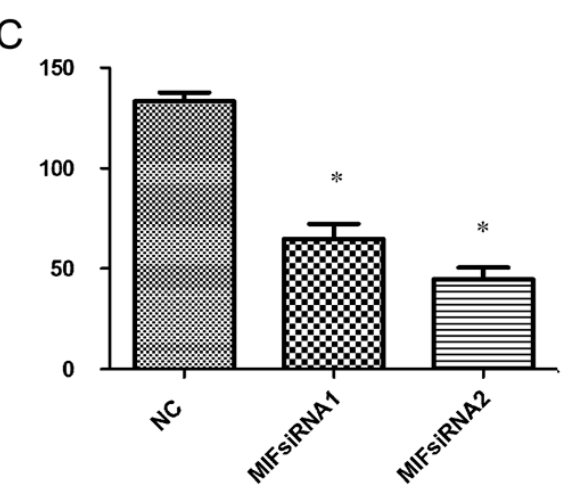

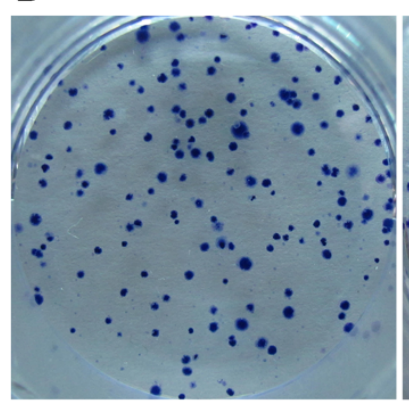

NS

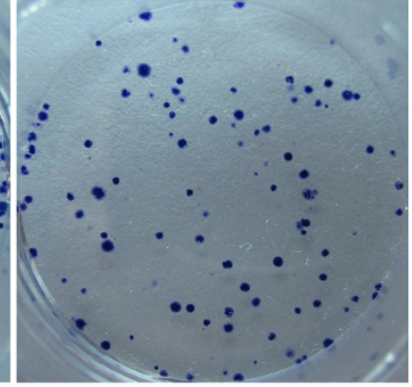

MIF SiRNA1

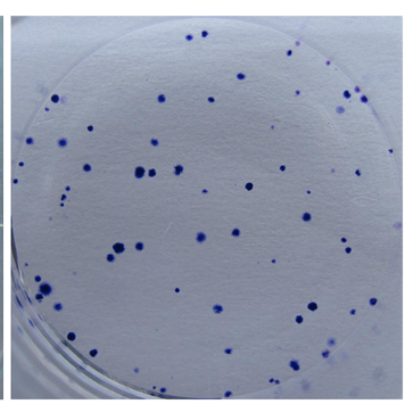

MIF siRNA1

Figure 4 Effect of MIF siRNA on the proliferation of H460 cells. (A); MTT assay showed that treatment of H460 cells with MIF siRNA inhibited their proliferation. Each point in the curve represents the arithmetic mean OD values \pm SD from representative experiments that were performed in triplicate. (B); Plate cloning assay indicated that MIF siRNA inhibited the proliferation of H460 cells. Image (C); Quantification of the data obtained from the plate cloning experiments. Data were expressed as arithmetic mean \pm SD, Indicated levels of statistical significance were; *: $P<0.05$ as compared with the NC Group. NS: Negative control group. 


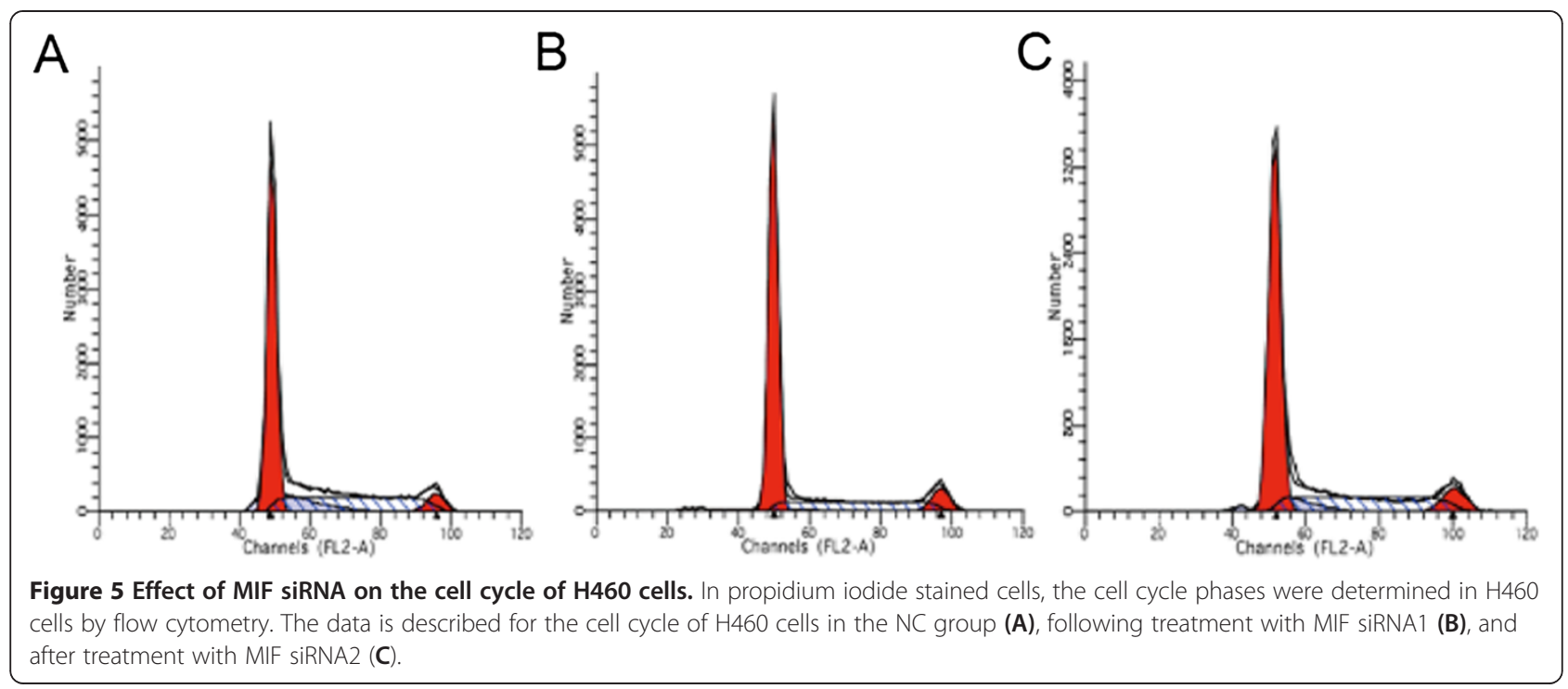

groups (Figure 7A), while the expression of both caspase-8 (Figure 7A) and Akt in $\mathrm{H} 460$ cells remained unaltered (Figure 7B) irrespective of the siRNA treatment. Collectively, these observations suggest that MIF siRNA not only blocks cell proliferation of H460 cells, but also promotes an apoptotic mode of programmed cell death that may be dependent, at least in part, on enhanced cleavage of pro-caspases- 3 and -4 to their mature functional procaspase counterparts (i.e. caspase- 3 and -4) (Figure 7A).
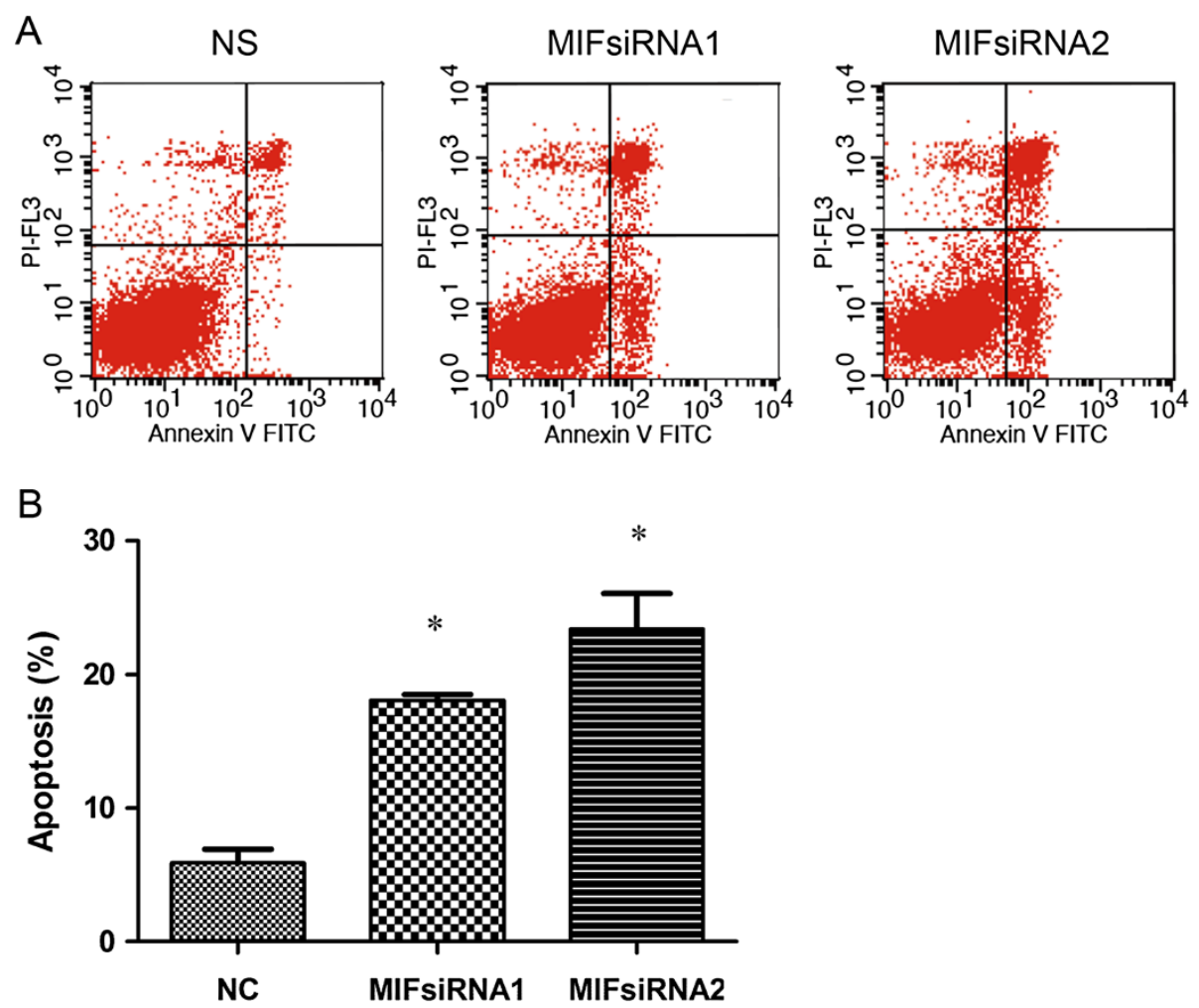

Figure 6 Flow cytometric determination of the effect of MIF siRNA on Apoptosis of H460 cells. (A); Cultured H460 cells were divided into three groups: A: cells transfected with NC siRNA, (B) and (C); cells transfected with MIF siRNA (siRNA1 or siRNA2 respectively). After a $48 \mathrm{~h}$ treatment, the cells were harvested for quantitation of apoptosis by determining changes in the cell surface expression of Annexin-V. (B) shows a description of the observed frequency of cells undergoing apoptosis which were found to be much higher in the MIF siRNA1 (18.09 $\pm 0.41 \%)$ and MIF siRNA2 $(23.38 \pm 2.67 \%)$ treated groups than in the negative control $(N C)$ treated group $(5.87 \pm 1.05$ and $p<0.05)$ of H460 cells respectively. 
A

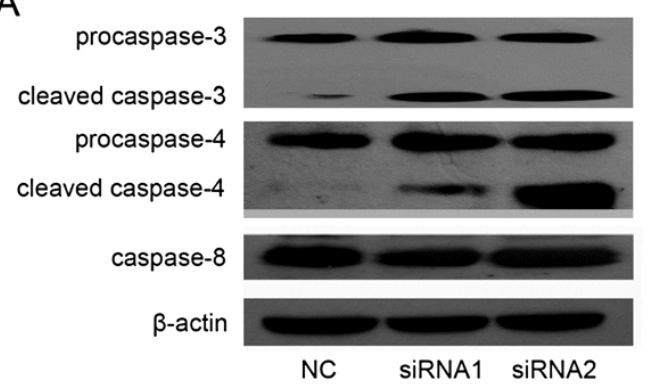

B

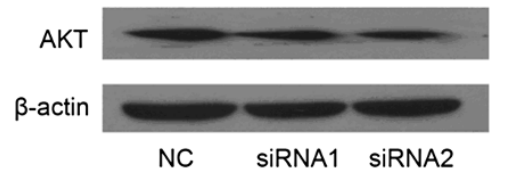

Figure 7 Effects of MIF siRNA on cellular expression of caspase-3, caspase-4, caspase-8 and Akt in H460 cells. To determine the expression of caspase-3, caspase-4, caspase-8 $(\mathbf{A})$ and Akt (B) in differentially siRNA-treated H460 cells, cultures were harvested after a 48 h treatment, and protein expression patterns assessed by Western immunoblotting analysis and ECL with an appropriate dilution of specific primary antibodies. Beta-actin was used as loading control for all proteins studied.

\section{Discussion}

Several reports in the literature have indicates the critical role of MIF as a regulator of innate and adaptive immunity, inflammation and tumor progression [16,42]. Increased expression of MIF has been reported in hepatocellular carcinoma, prostate carcinoma, lung adenocarcinoma, neuroblastoma and colorectal cancers [13,24,25,27,29]. High expression of MIF in lung cancer patients predicts a worse prognosis for disease free and overall survival $[11,43]$. It has been shown that CD74 was the cell surface receptor for MIF [10,38], and that MIF promotes sustained ERK/ MAPK activation through occupation of the cell surface CD74 receptor [44,45].

A number of reports have shown that MIF is capable of blocking p53-dependent apoptosis [46], and can activate the PI3K/Akt pathway [47,48], as well as promoting endothelial cell proliferation and differentiation [49-51]. These findings confirm that MIF plays an important role in the development and promotion of human malignancies. Since many of the mechanisms responsible for the multifactorial functions of MIF have still to be identified, we have provided important new information with regard to the role of MIF in regulating tumor cell proliferation and programmed cell death by caspase- 3 and caspase-4 dependent pathways.

In our study, knockdown of the functional expression of MIF markedly decreased H460 cell proliferation and induced apoptosis as seen by augmented expression of Annexin-V following treatment of $\mathrm{H} 40$ cells by MIF siRNA. Additionally, caspases plays an essential role in cell apoptosis and indeed most cell-inducing stimuli direct apoptosis through the activation of a specific sequence of caspase proteins. Caspases are cysteine proteases, and functionally related to interleukin- $1 \beta$ converting enzyme (ICE). Activation of ICE-like proteases by stimuli that trigger apoptosis, act on substrates such as poly(ADP-ribose) polymerase or PARP, and activate other enzymes such as endonucleases and transglutaminase, which leads to energy (ATP and ADP) depletion, ER stress, protease activation, cytoskeletal disorganization, and apoptotic body formation. Thus, the enhanced cleavage of pro-caspase- 3 and procaspase- 4 to their biologically active pro-caspase counterparts that we found in this study following treatment of H40 cells with MIF siRNA, is a key feature of the highly regulated cell death process of apoptosis.

Significant evidence has accumulated suggesting that the endoplasmic reticulum (ER) plays a crucial role in the execution of apoptosis [52,53]. For example, caspase-12, has been shown to induce apoptosis in response to ER stress [54] and in humans, the ER-mediated killing role of caspase- 12 has been found to be substituted by caspase- 4 $[54,55]$. Moreover, caspase- 4 has been found to be a specific mediator of ER stress and may play an important role in the ER-stress pathway $[55,56]$.

By contrast, caspase 3 is downstream effector protein, and it takes part in the functionally crucial decision and execution phases of the apoptosis process [57]. Caspase8 is generally considered to be an initiator caspase due to its ability to be associated with the cell surface death receptor that transduces apoptosis via the structural signaling complexes FADD/MORT1 and RAIDD/TRADD. Indeed, the amino terminal of the death effector domain (DED) of FADD/MORT1 is required for death induction and interacts structurally with the prodomain of caspase-8, which recruits the FLICE/MACH death effector proteins that implement apoptosis.

In our study, the expression of the cleaved band of both caspase- 3 and caspase- 4 are significantly increased in the MIF siRNA groups. This data not only suggests that siRNA-mediated knockdown of MIF can promote cellular apoptosis in human lung $\mathrm{H} 460$ cells, but does so in caspase- 3 and caspase-4 dependent mechanism. It is tempting to speculate that the ER-stress pathway is involved in this process following pro-caspase cleavage and activation, yet this will need to await formal demonstration in our model system described in the current work.

In conclusion, we have shown that MIF increases the proliferation and blocks, at least in part, the apoptosis of 
H460 cells via caspase- 3 and caspase- 4 dependent pathways under conditions where the functional expression or activity of both caspase- 8 and the Akt signaling pathway remains unaltered. We propose that dampening of the functional expression of MIF could reasonably be exploited as a clinically useful strategy in the management of many tumors including lung cancer.

\section{Abbreviations}

MIF: Macrophage migration inhibitory factor; siRNA: Small interfering RNA; ER-stress: Endoplasmic Reticulum Stress; PI: Propidium iodide;

PI3K: Phosphoinositide 3-kinase; AKt/PKB: Protein Kinase.

\section{Competing interests}

The authors declare that there are no conflicts of interests.

\section{Authors' contributions}

YBG: Conceived and designed the experiments; JNH, DJW: Performed the experiments and analyzed the data; YFL, HLY: Contributed reagents/materials. All authors read an approved the final draft.

\section{Acknowledgements}

This work was supported by grants from The Natural Science Funds of Guangdong Province (No.10151008901000242), and the Science and Technology Project of Guangdong Province (2010B080701010).

\section{Author details}

${ }^{1}$ Department of Pulmonary Medicine, the First Affiliated Hospital of Sun Yat-Sen University, Guangzhou 510080, China. ${ }^{2}$ Department of Physiopathology, Zhongshan School of Medicine, Sun Yat-Sen University, Guangzhou 510080, China.

Received: 24 September 2012 Accepted: 28 February 2013 Published: 24 March 2013

\section{References}

1. Jemal A, Siegel R, Xu J, Ward E: Cancer statistics, 2010. CA Cancer J Clin 2010, 60(5):277-300.

2. Schiller JH, Harrington D, Belani CP, Langer C, Sandler A, Krook J, Zhu J, Johnson $\mathrm{DH}$ : Comparison of four chemotherapy regimens for advanced non-small-cell lung cancer. N Engl J Med 2002, 346(2):92-98.

3. Sandler A, Gray R, Perry MC, Brahmer J, Schiller JH, Dowlati A, Lilenbaum R, Johnson DH: Paclitaxel-carboplatin alone or with bevacizumab for nonsmall-cell lung cancer. N Engl J Med 2006, 355(24):2542-2550.

4. Carney DN: Lung cancer-time to move on from chemotherapy. New Engl J Med 2002, 346(2):126-128.

5. Calandra T, Bernhagen J, Mitchell RA, Bucala R: The macrophage is an important and previously unrecognized source of macrophage migration inhibitory factor. J Exp Med 1994, 179(6):1895-1902.

6. Bacher M, Metz CN, Calandra T, Mayer K, Chesney J, Lohoff M, Gemsa D, Donnelly T, Bucala R: An essential regulatory role for macrophage migration inhibitory factor in T-cell activation. Proc Natl Acad Sci USA 1996, 93(15):7849-7854.

7. Rossi AG, Haslett C, Hirani N, Greening AP, Rahman I, Metz CN, Bucala R, Donnelly SC: Human circulating eosinophils secrete macrophage migration inhibitory factor (MIF). Potential role in asthma. J Clin Invest 1998, 101(12):2869-2874.

8. Imamura K, Nishihira J, Suzuki M, Yasuda K, Sasaki S, Kusunoki Y, Tochimaru $\mathrm{H}$, Takekoshi Y: Identification and immunohistochemical localization of macrophage migration inhibitory factor in human kidney. Biochem $\mathrm{Mol}$ Biol Int 1996, 40(6):1233-1242.

9. Nishihira J, Koyama Y, Mizue Y: Identification of macrophage migration inhibitory factor (MIF) in human vascular endothelial cells and its induction by lipopolysaccharide. Cytokine 1998, 10(3):199-205.

10. McClelland M, Zhao L, Carskadon S, Arenberg D: Expression of CD74, the receptor for macrophage migration inhibitory factor, in non-small cell lung cancer. Am J Pathol 2009, 174(2):638-646.

11. White ES, Flaherty KR, Carskadon S, Brant A, lannettoni MD, Yee J, Orringer $M B$, Arenberg DA: Macrophage migration inhibitory factor and CXC chemokine expression in non-small cell lung cancer: role in angiogenesis and prognosis. Clin Cancer Res 2003, 9(2):853-860.

12. Kayser K, Nwoye JO, Kosjerina Z, Goldmann T, Vollmer E, Kaltner H, Andre S, Gabius $\mathrm{HJ}$ : Atypical adenomatous hyperplasia of lung: its incidence and analysis of clinical, glycohistochemical and structural features including newly defined growth regulators and vascularization. Lung Cancer 2003, 42(2):171-182.

13. Rendon BE, Roger T, Teneng I, Zhao M, Al-Abed Y, Calandra T, Mitchell RA: Regulation of human lung adenocarcinoma cell migration and invasion by macrophage migration inhibitory factor. J Biol Chem 2007, 282(41):29910-29918.

14. Hauck CR, Sieg DJ, Hsia DA, Loftus JC, Gaarde WA, Monia BP, Schlaepfer DD: Inhibition of focal adhesion kinase expression or activity disrupts epidermal growth factor-stimulated signaling promoting the migration of invasive human carcinoma cells. Cancer Res 2001, 61(19):7079-7090.

15. Chan AY, Coniglio SJ, Chuang YY, Michaelson D, Knaus UG, Philips MR, Symons M: Roles of the Rac1 and Rac3 GTPases in human tumor cell invasion. Oncogene 2005, 24(53):7821-7829.

16. Conroy H, Mawhinney L, Donnelly SC: Inflammation and cancer: macrophage migration inhibitory factor (MIF)-the potential missing link. QJM 2010, 103(11):831-836.

17. Cooke G, Armstrong ME, Donnelly SC: Macrophage migration inhibitory factor (MIF), enzymatic activity and the inflammatory response. Biofactors 2009, 35(2):165-168.

18. Bach JP, Rinn B, Meyer B, Dodel R, Bacher M: Role of MIF in inflammation and tumorigenesis. Oncology 2008, 75(3-4):127-133.

19. Bucala R, Donnelly SC: Macrophage migration inhibitory factor: a probable link between inflammation and cancer. Immunity 2007, 26(3):281-285.

20. Ralph JA, Ahmed AU, Santos LL, Clark AR, McMorrow J, Murphy EP, Morand EF: Identification of NURR1 as a mediator of MIF signaling during chronic arthritis: effects on glucocorticoid-induced MKP1. Am J Pathol 2010, 177(5):2366-2378.

21. Lehmann LE, Book M, Hartmann W, Weber SU, Schewe JC, Klaschik S, Hoeft A, Stuber F: A MIF haplotype is associated with the outcome of patients with severe sepsis: a case control study. J Transl Med 2009, 7:100.

22. Shiroeda H, Tahara T, Nakamura M, Shibata T, Nomura T, Yamada H, Hayashi $R$, Saito T, Yamada M, Fukuyama T, et al: Association between functional promoter polymorphisms of macrophage migration inhibitory factor (MIF) gene and ulcerative colitis in Japan. Cytokine 2010, 51(2):173-177.

23. Takahashi N, Nishihira J, Sato $Y$, Kondo M, Ogawa H, Ohshima T, Une Y, Todo S: Involvement of macrophage migration inhibitory factor (MIF) in the mechanism of tumor cell growth. Mol Med 1998, 4(11):707-714.

24. Hira E, Ono T, Dhar DK, El-Assal ON, Hishikawa Y, Yamanoi A, Nagasue N: Overexpression of macrophage migration inhibitory factor induces angiogenesis and deteriorates prognosis after radical resection for hepatocellular carcinoma. Cancer 2005, 103(3):588-598.

25. Meyer-Siegler KL, Bellino MA, Tannenbaum M: Macrophage migration inhibitory factor evaluation compared with prostate specific antigen as a biomarker in patients with prostate carcinoma. Cancer 2002, 94(5):1449-1456.

26. Binsky I, Haran M, Starlets D, Gore Y, Lantner F, Harpaz N, Leng L, Goldenberg DM, Shvidel L, Berrebi A, et al: IL-8 secreted in a macrophage migration-inhibitory factor- and CD74-dependent manner regulates $B$ cell chronic lymphocytic leukemia survival. Proc Natl Acad Sci USA 2007, 104(33):13408-13413.

27. Legendre H, Decaestecker C, Nagy N, Hendlisz A, Schuring MP, Salmon I, Gabius HJ, Pector JC, Kiss R: Prognostic values of galectin-3 and the macrophage migration inhibitory factor (MIF) in human colorectal cancers. Mod Pathol 2003, 16(5):491-504.

28. Khan N, Cromer CJ, Campa M, Patz EF Jr: Clinical utility of serum amyloid A and macrophage migration inhibitory factor as serum biomarkers for the detection of nonsmall cell lung carcinoma. Cancer 2004, 101(2):379-384.

29. Tomiyasu M, Yoshino I, Suemitsu R, Okamoto T, Sugimachi K: Quantification of macrophage migration inhibitory factor mRNA expression in nonsmall cell lung cancer tissues and its clinical significance. Clin Cancer Res 2002, 8(12):3755-3760.

30. Lai KN, Leung JC, Metz CN, Lai FM, Bucala R, Lan HY: Role for macrophage migration inhibitory factor in acute respiratory distress syndrome. J Pathol 2003, 199(4):496-508.

31. Donnelly SC, Bucala R: Macrophage migration inhibitory factor: a regulator of glucocorticoid activity with a critical role in inflammatory disease. Mol Med Today 1997, 3(11):502-507.

32. Ren Y, Chan HM, Li Z, Lin C, Nicholls J, Chen CF, Lee PY, Lui V, Bacher M, Tam PK: Upregulation of macrophage migration inhibitory factor 
contributes to induced N-Myc expression by the activation of ERK signaling pathway and increased expression of interleukin-8 and VEGF in neuroblastoma. Oncogene 2004, 23(23):4146-4154.

33. Jung $\mathrm{H}$, Seong $\mathrm{HA}, \mathrm{Ha} \mathrm{H}$ : Critical role of cysteine residue 81 of macrophage migration inhibitory factor (MIF) in MIF-induced inhibition of p53 activity. J Biol Chem 2008, 283(29):20383-20396.

34. Kyriakis JM: Thinking outside the box about Ras. J Biol Chem 2009, 284(17):10993-10994.

35. White ES, Strom SR, Wys NL, Arenberg DA: Non-small cell lung cancer cells induce monocytes to increase expression of angiogenic activity. I Immunol 2001, 166(12):7549-7555.

36. Arenberg DA, Polverini PJ, Kunkel SL, Shanafelt A, Hesselgesser J, Horuk R, Strieter RM: The role of $\mathrm{CXC}$ chemokines in the regulation of angiogenesis in non-small cell lung cancer. J Leukoc Biol 1997, 62(5):554-562.

37. Arenberg D, Luckhardt TR, Carskadon S, Zhao L, Amin MA, Koch AE: Macrophage migration inhibitory factor promotes tumor growth in the context of lung injury and repair. Am J Respir Crit Care Med 2010, 182(8):1030-1037.

38. Leng L, Metz CN, Fang Y, Xu J, Donnelly S, Baugh J, Delohery T, Chen Y, Mitchell RA, Bucala R: MIF signal transduction initiated by binding to CD74. J Exp Med 2003, 197(11):1467-1476

39. Shun CT, Lin JT, Huang SP, Lin MT, Wu MS: Expression of macrophage migration inhibitory factor is associated with enhanced angiogenesis and advanced stage in gastric carcinomas. World J Gastroenterol 2005, 11(24):3767-3771.

40. Beswick EJ, Pinchuk IV, Minch K, Suarez G, Sierra JC, Yamaoka Y, Reyes VE: The Helicobacter pylori urease $B$ subunit binds to CD74 on gastric epithelial cells and induces NF-kappaB activation and interleukin-8 production. Infect Immun 2006, 74(2):1148-1155.

41. Gamez-Pozo A, Sanchez-Navarro I, Calvo E, Agullo-Ortuno MT, Lopez-Vacas R, Diaz E, Camafeita E, Nistal M, Madero R, Espinosa E, et al: PTRF/cavin-1 and MIF proteins are identified as non-small cell lung cancer biomarkers by label-free proteomics. PLoS One 2012, 7(3):e33752.

42. Calandra T, Roger T: Macrophage migration inhibitory factor: a regulator of innate immunity. Nat Rev Immunol 2003, 3(10):791-800.

43. Kamimura A, Kamachi M, Nishihira J, Ogura S, Isobe H, Dosaka-Akita H, Ogata A, Shindoh M, Ohbuchi T, Kawakami Y: Intracellular distribution of macrophage migration inhibitory factor predicts the prognosis of patients with adenocarcinoma of the lung. Cancer 2000, 89(2):334-341.

44. Mitchell RA: Mechanisms and effectors of MIF-dependent promotion of tumorigenesis. Cell Signal 2004, 16(1):13-19.

45. Lue H, Kapurniotu A, Fingerle-Rowson G, Roger T, Leng L, Thiele M, Calandra T, Bucala R, Bernhagen J: Rapid and transient activation of the ERK MAPK signalling pathway by macrophage migration inhibitory factor (MIF) and dependence on JAB1/CSN5 and Src kinase activity. Cell Signal 2006, 18(5):688-703.

46. Hudson JD, Shoaibi MA, Maestro R, Carnero A, Hannon GJ, Beach DH: A proinflammatory cytokine inhibits p53 tumor suppressor activity. J Exp Med 1999, 190(10):1375-1382.

47. Li GQ, Xie J, Lei XY, Zhang L: Macrophage migration inhibitory factor regulates proliferation of gastric cancer cells via the PI3K/Akt pathway. World J Gastroenterol 2009, 15(44):5541-5548.

48. Lue H, Thiele M, Franz J, Dahl E, Speckgens S, Leng L, Fingerle-Rowson G, Bucala R, Luscher B, Bernhagen J: Macrophage migration inhibitory factor (MIF) promotes cell survival by activation of the Akt pathway and role for CSN5/JAB1 in the control of autocrine MIF activity. Oncogene 2007, 26(35):5046-5059.

49. Amin MA, Volpert OV, Woods JM, Kumar P, Harlow LA, Koch AE: Migration inhibitory factor mediates angiogenesis via mitogen-activated protein kinase and phosphatidylinositol kinase. Circ Res 2003, 93(4):321-329.

50. Chesney J, Metz C, Bacher M, Peng T, Meinhardt A, Bucala R: An essential role for macrophage migration inhibitory factor (MIF) in angiogenesis and the growth of a murine lymphoma. Mol Med 1999, 5(3):181-191.

51. Xu X, Wang B, Ye C, Yao C, Lin Y, Huang X, Zhang Y, Wang S: Overexpression of macrophage migration inhibitory factor induces angiogenesis in human breast cancer. Cancer Lett 2008, 261(2):147-157.

52. Rao RV, Hermel E, Castro-Obregon S, del Rio G, Ellerby LM, Ellerby HM, Bredesen DE: Coupling endoplasmic reticulum stress to the cell death program. Mechanism of caspase activation. J Biol Chem 2001, 276(36):33869-33874.

53. Oyadomari S, Araki E, Mori M: Endoplasmic reticulum stress-mediated apoptosis in pancreatic beta-cells. Apoptosis 2002, 7(4):335-345.
54. Nakagawa T, Yuan J: Cross-talk between two cysteine protease families. Activation of caspase-12 by calpain in apoptosis. J Cell Biol 2000, 150(4):887-894.

55. Hitomi J, Katayama T, Eguchi Y, Kudo T, Taniguchi M, Koyama Y, Manabe T, Yamagishi S, Bando Y, Imaizumi K, et al: Involvement of caspase-4 in endoplasmic reticulum stress-induced apoptosis and Abeta-induced cell death. J Cell Biol 2004, 165(3):347-356.

56. Li Z, Zhang T, Dai H, Liu G, Wang H, Sun Y, Zhang Y, Ge Z: Endoplasmic reticulum stress is involved in myocardial apoptosis of streptozocininduced diabetic rats. J Endocrinol 2008, 196(3):565-572.

57. MacFarlane M: TRAlL-induced signalling and apoptosis. Toxicol Lett 2003, 139(2-3):89-97.

doi:10.1186/1475-2867-13-28

Cite this article as: Guo et al.: Functional disruption of macrophage migration inhibitory factor (MIF) suppresses proliferation of human H460 lung cancer cells by caspase-dependent apoptosis. Cancer Cell International 2013 13:28.

\section{Submit your next manuscript to BioMed Central and take full advantage of:}

- Convenient online submission

- Thorough peer review

- No space constraints or color figure charges

- Immediate publication on acceptance

- Inclusion in PubMed, CAS, Scopus and Google Scholar

- Research which is freely available for redistribution 